\title{
A Theological Assessment of the Covenant between Judas Maccabeus and Rome: an Intertextual Analysis of 1 Macc 8:17-20
}

\section{Introduction}

The subject of this article undertakes more detailed research on the biblical interpretation of the conduct of Jews in the final stage of the history of Israel. This research is done in the context of the Law of Moses before the onset of the New Testament. It is now a well-known fact that the Deuteronomic tradition of the Old Testament holistically evaluated the history of the chosen people, the doings of their rulers in the North and South, as well as the behavior of all the people of the covenant. The most vivid example of this evaluation is 2 Kings 17:1-18, which relates the capture of Samaria and the downfall of the Northern Kingdom in 622. The hagiographer provided a theological assessment of the sequence of events which ended the political existence of Israel. The Southern Kingdom was slowly dying due to its own infidelities. However, the period of the second temple in its final stage, which is dated at the $2^{\text {nd }}$ cent. $\mathrm{BC}$, is examined to a lesser extent. For instance, both Maccabean Books are studied more rarely, especially in the context of the well-established exegesis of the Protocanonical books of the Hebrew Bible. Therefore, it is obvious that scholars devote more attention to these books in their biblical research. The Books of the Maccabees belong to the historical

\footnotetext{
${ }^{1}$ Rev. Janusz Nawrot, prof. dr hab. — born in 1960 in Międzychód, Wielkopolskie Province; a priest of the Archdiocese of Poznań since 1985; a lecturer at Adam Mickiewicz University in Poznań; member of the Historical Theology Department; specialised in exegesis and theology of the Old Testament; e-mail: jannaw@amu.edu.pl. ORCID: 0000-0002-2498-5081.
} 
canon of the Holy Scripture, where the Deuteronomic school of thought plays the most prominent role out of all the three great trends in the Old Testament. Evaluation of what the rulers of Israel and Judah did in the context of their fidelity to God's commandments served as an impulse to continue such an interpretation of the history of Israel in the centuries to come.

This article is the third and final part of the exegetic trilogy which was initiated with the analysis of Law texts forbidding covenants with Gentile communities. The second part included the exegesis of several leading fragments that were subject to these prohibitions. ${ }^{2}$ It also examined examples of covenants and pacts between biblical characters and rulers of the neighboring nations. These covenants and pacts did not fall under the Mosaic prohibitions when their aim or basis was of a political or commercial character and when they were not related to the possibility of losing faith in the one and only God of Israel. Such a danger was not an option only in the case of Abraham and Abimelech (Gen 21:27,32) along with Solomon and Hiram (1 Kings 5:26). The threat of the nation losing faith occurred only in the negotiations between Asa and Ben-Hadad II (1 Kings 21:1-34), Ahaz and Tiglath-Pileser III (2 Kings 16:7-9; 2 Chr 28:16-21), the kingdom of Judah and Egypt (Isa 30:1-5), and finally the pact between Zedekiah and Nebuchadnezzar II (Ezek 17:13). In all of these examples, political endeavors between the rulers of Israel and Judah and the Gentile monarchs resulted, in fact, in the rejection of the covenant with the God of Israel. ${ }^{3}$

According to the biblical narrative, Judas Maccabeus served as a representative of his people and sent his messengers to Rome in ca. $161 \mathrm{BC}^{4}$ although he did not bear any official title by law that would entitle him to represent his people. Thus the Roman republic could only be interested in Judas's activities which led

2 J. Nawrot, Izrael wobec zakazu sprzymierzania się z poganami w wybranych tekstach Septuaginty: część I, PST 34 (2019), pp. 7-28.

${ }^{3}$ Id., Alliances between Israel and Other Nations in Light of the Pentateuch's Prohibitions in the Greek Bible, PST 35 (2020), pp. 29-48.

${ }_{4}$ There are different evaluations of historicity of the alliance between Judas Maccabeus, Jews and the republic. For M. Stern, there is no point in doubting the authenticity of the treaty assuming that it is linked to Timarchus's rebellion in the Eastern part of the Seleucid empire. It is possible that this rebellion had a great impact on the decision of the Roman senate to sign a treaty with Judas, see: M. Stern, The Treaty between Judaea and Rome in 161 BCE, "Zion" 51 (1986), pp. 3-28. On the other hand, the document between Judas and Rome is not mentioned in non-Jewish records. According to L. Zollschan, it is highly improbable that the pact could have been signed in 161 BC, see: L. Zollschan, The Senate and the Jewish Embassy of 161 BCE [in:] The Path of Peace: Studies in Honor of Israel Friedman Ben-Shalom, ed. by D. Gera et al., Beersheva 2005, pp. 1-37. Besides, as was already claimed by L. Mendelssohn, the Jewish envoys succeeded in gaining the status of a political amicitia from the Roman senate as Romans did not want to confer the status foedus to countries which were not independent. This status was achieved by Jews only at the time of Simon Maccabeus. For further discussion see: M. Rocca, The Late Roman Republic and Hasmonean Judaea, "Athenaeum" 102 (2014) 1, p. 55. 
him to victories over the great rulers of the Seleucid monarchy. ${ }^{5}$ Some researchers treat Judas's turn to Rome as a historical fact especially after some unsuccessful negotiations between himself and Nicanor (7:29). There could have been an agreement during the meeting between the leader of the imperial troops and the commander of the revolt whereby Judas would take over the role of archpriest occupied by Alcimus, which would have eased the revolt against the empire. Thus it should come as no surprise that Alcimus made it impossible for both rulers to reach possible resolutions. He also remained in office in Judah, which prevented Judas from seizing power over the people, especially over the part of the community which was interested in cooperation with Seleucids. This would have meant being in favor of Alcimus's retention of his office as archpriest. Judas's turn to Rome would have resulted in the weakening of power of the villainous archpriest. This power was based on the Seleucid king and his army. According to the Roman guarantees, Judas could have become archpriest thanks to the wide support from his adherents and the patriotic masses, ${ }^{6}$ and irrespective of Seleucids. In this case, Judas further developed his political instinct. He also gave the republic one more way of interfering in the internal affairs of the Seleucid empire ${ }^{7}$ through reliance on Rome. The fact that Judah did not play a major role in the imperialistic plans of the republic could mean that the messengers from this region would be treated like a means by the senate. Thus the following question remains open - did the leader of the revolt believe in the sincerity of Rome or did he consciously let the empire use him? Was he merely a puppet in the grand politics of the Middle East of those times? He could have believed that there would be crumbs left over from the grand table of Rome's political feast for him. ${ }^{8}$

Intertextual analysis will serve as the scientific method of analyzing biblical material. This method was drafted in one of the earlier articles. ${ }^{9}$ Therefore, the general rules behind this methodology will not be repeated here. In this particular case, the method of combining vocabulary present in selected verses from the First Book of Maccabees with the terminology from the earlier books of the Greek Bible will be employed. This technique will serve to show the concurrence

5 J. Goldstein, I Maccabees: A New Translation, with Introduction and Commentary, AB 41, Garden City 1976, p. 357.

${ }^{6}$ C. Seeman, Rome and Judea in Transition: Hasmonean Relations with the Roman Republic and the Evolution of the High Priesthood, New York 2013, p. 6.

${ }^{7}$ B. Bar-Kochva, Judas Maccabaeus: The Jewish Struggle Against the Seleucids, Cambridge 2002, p. 86.

${ }^{8}$ Ultimately, other allies of the republic along with its political clientele were able to win something for themselves, see: D. Gera, Judaea and Mediterranean Politics: 219 to 161 B.C.E., Leiden-New York 1998, p. 254.

9 J. Nawrot, Aluzje literackie w teologicznej ocenie działań arcykapłana Szymona w 1 Mch 14,5, BibAn 11 (2021) 1, pp. 5-23. 
of the theological thought in the analyzed verses. The application of some intentional allusions will expose the literary intention of the inspired author. These allusions are the most visible literary effort present in the First Book of Maccabees. The decision made by the leader of the Maccabean Revolt was laconically mentioned by the author in 1 Macc 8:17-20. Each of these verses has its own significance and theological meaning and as such is worthy of careful analysis.

\section{Judas Maccabeus's Selection of Messengers}

It is noteworthy that the ending of the presented verse thematically matches the main objective of the covenant that is being made. However, the clear morphological relationship between the verbs and the allusion to some Old Testament quotations requires that the entire text should remain in one place.

\section{8:17: So Judas chose Eupolemus, son of John, son of Accos, and Jason, son of Eleazar, and sent them to Rome to establish friendship and alliance with them.}

The initiative to negotiate with the Roman republic came from Judas and his insurgents, which is peculiar because, as recounted by Flavius Josephus, only the archpriest could have represented his nation by taking outside political decisions..$^{10}$ It is not easy to historically resolve Alcimus's matter or determine whether Judas really bore the title of archpriest. The fact that the copies of some official letters did not mention Judas adds to this uncertainty. Besides, it can be suspected that Demetrius I would have never agreed to the bestowal of the title of an archpriest upon an enemy of the empire. Thus, some other Jewish groups who were unfavorable of Alcimus could have acted on their own initiative. This disfavor resulted particularly from Alcimus's treason and murder of

${ }^{10}$ See: Ant. 11:4,8,111 and CAp 2:21,185; 22,188. Since according to the First Book of Maccabees, Alcimus was archpriest, Flavius probably moved the moment of his death after Judas's victory over Nicanor while ignoring the last days of the ungodly archpriest in 1 Macc 9:54-57. The Jewish historian might have assumed that Judas was proclaimed archpriest after the death of Alcimus (Ant. 12:10,6,414,419). This record would fill the resultant legal loophole and Judas would be granted an official title to carry out his initiative. Assuming that Flavius included a historical note, then the pact with the republic must have been signed after the death or removal from office of Alcimus, which would have been later than the text of the book indicates. So the order of the death of both characters would have been switched. The hated archpriest died, according to the hagiographer, right after killing Judas in the Battle of Elasa (9:56). See: J. Goldstein, I Maccabees..., p. 358. 
those representatives of the community who were willing to compromise with the imperial officials $(7: 12-18)$.

Meanwhile, the hagiographer recounts a situation which arose as a result of the actions of Demetrius I and his leaders. ${ }^{11}$ This situation forced the insurgents to make a pact with the only country which could positively reverse the difficult military condition of the revolt. While reading the passage $8: 1-16$, one can have the impression that the given rules which influence the republic constitute the entire knowledge about Romans in the Middle East. It is worthy of pointing out that this knowledge concerns only the politico-social sphere of its functioning. There is a lack of reference to Roman religiousness, faith, worship etc. Most likely the hagiographer intentionally omitted affairs related to religion so as to underscore that this sphere of life was of no interest to the insurgents who were focused solely on the expected military-political benefits resulting from the pact. Such priorities took possession of the hearts of the leaders of the Maccabean Revolt. They did not care about the pact's actual agreement with the provisions of the Law of Moses. The strategic aims limited to some concrete effects of the signed pact played the most important role.

The author announces Judas and other leaders' decision to send (apesteilen) two trustworthy representatives who have been granted every authorization to establish (stēsai) a treaty. Jer 43:21 (LXX) deserves special attention out of all the texts in the Greek Bible as it includes this two-part sequence of verbs in the mentioned order. ${ }^{12}$ Jer 43:21-23 recounts the villainous behavior of King Joakim who sent (apesteilen) one of his servants to retrieve a prophetic scroll and read it aloud in the presence of all the king's advisors standing (hestēkotōn) beside him. After the announcement of the prophecy, which was extremely unfavorable to the nation, the ruler cut off and destroyed the fragment of God's word (v. 22-23). ${ }^{13}$ One might ask: what brings both texts closer to each other? For one, there is similar vocabulary and both verbs (apostello- - histemi) occur herein. The presence of these verbs might have to do with an allusion intended by the author of the First Book of Maccabees. For many specialists that deal with intertextuality in the Bible this allusion in undoubtedly the most important feature which creates

${ }^{11}$ Chapter 7 of the book mentions a new stage of battle between the Seleucid monarchy and the insurgents during the reign of Demetrius I. This new stage involves the actions of Bacchides and Nicanor, the leaders of the imperial troops who permanently troubled the Maccabees and their supporters.

${ }_{12}$ The same order of both terms also occurs in 1 Sam 19:20; 2 Kings 23:16; 1 Chr 12:15; 1 Macc 7:9; Isa 36:2, as well as in Jer 19:14. Considering the context, content or characters of particular events, these quotations are either distant or they completely do not fit in with the theme of the analyzed verse. It is almost certain that the hagiographer did not refer to the events he described in theological terms.

${ }^{13}$ G.L. Keown, P.J. Scalise, T.G. Smithers, Jeremiah 26-52, WBC 27, Dallas 1995, p. 206. 
a bridge between the analyzed verses ${ }^{14}$. One might encounter some interpretational difficulty here since both verbs involve completely different contexts and situations. But what is the link between these verbs? They might have several things in common:

a) a binding document: God's word (Jer) and a political treaty binding both parties (1 Macc);

b) the presence of a double power factor on both sides of the document: Jeremiah ${ }^{15} /$ Joakim (Jer) and Judas/the senate of the republic (1 Macc);

c) tension between the rejection of the document as a result of the ruler's arbitrary action expressed explicitly (Jer) and possibly the same attitude (1 Macc);

d) possible disappointment over the attitude of either side of the agreement/ covenant, which turns out to violate its provisions by rejecting it altogether.

By referring to this text, the hagiographer wants to announce in what way Romans will treat the pact signed with Jews when it ceases to fulfill the objectives that Romans outlined. The First Book of Maccabees shows that it was not the Jewish insurgents but the senate that defined the provisions of the treaty. What became a necessary condition for the Jews in their fight for religious survival ${ }^{16}$ might become a meaningless document for Romans whose political objectives could change or the situation could deviate from the original assumptions of the senate. Such a line of thought corresponds to how Joakim tore into pieces the consecutive phrases of Jeremiah's prophecy.

The prophetic text might shed important light on the conduct of Judas Maccabeus as entering into covenants with a Gentile superpower might, in fact, mean violation of the covenant with God. Like Joakim earlier, Judas will now cancel with his arbitrary decision what the Lord communicated through His word for the welfare of His people. Similarly to how the Judean king disobeyed the Lord's word, the leader of the revolt will now disregard the prohibition of making covenants with Gentiles, as it is noted in Deut 7:1-2. What is not so important is the

14 B.J. Oropeza, Quotes, Allusions, and Echoes: Some Thoughts about What They Mean in Reference to Biblical Scripture, https://www.academia.edu/38547991/Quotes_Allusions_and_ Echoes_Some_Thoughts_about_What_They_Mean_in_Reference_to_Scripture, p. 3 [accessed: 1.2.2021].

${ }^{15}$ Assuming that the prophet was treated as a 'power factor', he was so in the sense of being called by God (Jer 1:4-10) and speaking to the people due to His control over the entire chosen people. In the Book of Jeremiah, this control of God is expressed through the frequent 'ammî, i.e. 'my people', which is obviously due to the covenant made on Zion $(2: 13,31 ; 4: 11,22 ; 6: 14,26$; $7: 12 ; 8: 11,19,21-23 ; 9: 1,6 ; 12: 14,16 ; 14: 17 ; 15: 7 ; 18: 15 ; 23: 2,13,22,27,32 ; 30: 3 ; 33: 24 ; 50: 6$; 51:45).

${ }^{16}$ In his critical analysis of the First Book of Maccabees, S.R. Mandell claims that Jews believed in the validity of the treaty although its structure was not typical for international agreements, see: ead., Did the Maccabees Believe that They Had a Valid Treaty with Rome?, CBQ 53/2 (1991), pp. 218-220. 
manner in which God's word is rejected. The fact that the leaders of the people willfully refuse to observe the Law of the covenant is more important here. As this law should be unconditionally obeyed, the leaders discourage the entire community from obeying the Lord's Law. The end of life of the wicked king of Judah in 43:30-31, which is announced by Jeremiah on behalf of God, is symptomatic here. There is also a historical mention of Jer 44:1 (LXX), which is significant, too. In the first passage, God announces the lack of a royal descendant on the Judean throne and the humiliating death of the king whose corpse is not buried in a royal tomb but instead is exposed to the heat by day, and to the frost by night. ${ }^{17}$ In the second passage, the Lord announces the ascension to the throne by Zedekiah, the uncle of Joakim who has been taken into captivity. Zedekiah is nominated by Nebuchadnezzar, the king of Babylonia. A similar situation happened after the death of Judas when his brother Jonathan assumed power. Perhaps the hagiographer, in the context of the whole passage, refers to the unsuccessful model of political alliances noted in Isa 30:1-5. This model involves actions that are beyond God's will and as such are completely unsuccessful. These actions will eventually bring dishonor to those who undertook them.

The analyzed verse from the First Book of Maccabees might also make an allusion to 2 Kings 18:17 (LXX), where the victorious king of Assyria - Sennacherib - sent (apesteilen) two of his higher officials from the captured Lachish to Jerusalem. They were supposed to propose that the defenders of the town should surrender and accept Assyrian control over Judah. The officials stopped (estesan) by the aqueduct at the city gates and wanted to deliver a speech full of arrogance and faith in their invincibility (2 Kings 18:17-35). It is noteworthy that there are serious contextual and situational differences in this case. They concern the direction of the proposal to sign a pact. Yet the relations between both texts seem to be more important:

a) the proposal to sign a pact between Israel and the Gentiles: the ruler of Assyria/Hezekiah (2 Kings) and Judas/the Roman senate (1 Macc);

b) the presence of a power factor on both sides;

c) the activity of the messengers: the field commander ( 2 Kings) and the Jewish messengers (1 Macc);

d) the reverse of the circumstances of signing the pact: the Gentile ruler's proposal to the Judeans (2 Kings) and the Jews' proposal to the republic's senate (1 Macc).

17 The Hebrew biblical author included a wordplay here between tossing (hašle $k$ ) into fire Jeremiah's scroll by Joakim (v. 23) and throwing (mušleket) his carcass in the heat by day (v. 30). The Greek translator spotted this literary pun of the Hebrew author and included the same wordplay (erripten, v. 23), (errimmenon, v. 30), see: J.A. Thompson, The Book of Jeremiah, NICOT, Grand Rapids 2007, p. 629. 
The last point shows the real intentions of the Gentiles toward the Israelites when Assyria was a superpower. It also shows the real intentions of the Jews at the time of Judas Maccabeus, which has to do with yielding to the dictate of a more powerful party. Jews are therefore guided by the imperative not to make such agreements. Assuming that the intention of the author of the First Book of Maccabees was to compare his own account with 2 Kings 18:17 through a theological thread, Judas's intentions could be viewed as imprudence resulting from disregard of the lessons that Israel has had throughout history, namely that it could never expect anything positive from the Gentiles. Meanwhile Judas started to ignore God in his policies to provide security to his land by placing a bet on an uncertain alliance with a Gentile republic.

The author of the First Book of Maccabees uses the combination of filian kai symmachian, which translates as 'friendship and alliance'. This usage suggests that he had a good knowledge of the then political realities. There is a distinction between those who obliged themselves not to disrupt the republic's colonial policies and those who wanted to actively support it. ${ }^{18}$ Agreements defined with the use of the mentioned phrase were commonly signed in antiquity. ${ }^{19}$ According to the hagiographer, Romans signed pacts with whomever they wanted (8:1), so the Jewish people were not anyone special in this respect.

\section{The Main Aim of the Legation}

8:18: and to free themselves from the yoke; for they saw that the kingdom of the Hellenes was enslaving Israel

The author reveals the only objective of Jewish efforts, which is to sign a pact with the republic. This objective involves establishing protection from the attacks of the Seleucid monarchy. The insurgents were not able to oppose the entire mightiness of the empire. From a political point of view, this was a beneficial outcome whereby they would gain an ally that all the countries of the time had to

18 The same aim is also mentioned in 2 Macc 4:11, which describes a suspension of privileges that Jews possessed under the political agreement with Antiochus III the Great, see: $Ł$. Laskowski, Druga Księga Machabejska, NKB.ST XIV/3, Częstochowa 2017, pp. 218-219.

19 This is manifested through the terminological combination of filian kai symmachian in v. 17 , which refers to political agreements that were commonly signed in antiquity (Diodorus, Bibl. 9:10,5; 16:87,3; 17:49,3; 17:113:1; 20:46,1; Isocrates, Panath. 102,103,162; Pac. 139; Thucydides, Hist. Pel. 6:34,1; 8:108,4; Arrian, Anab. Alex. 2:14,2; 4:15,2; Polybius, Hist. 3:67,7; 3:97,5; 4:6,11; $4: 29,2 ; 7: 9,6 ; 21: 20,5 ; 28: 8,2 ; 32: 10,4)$. 
hold in high esteem. These countries would permanently send their ambassadors to take care of various matters of state. ${ }^{20}$

The Jewish messengers were not an equal partner for negotiation. Nevertheless, they sought military support for their insurrection and gave Rome a pretext to intervene in the conflicts between the Seleucid rulers and their disobedient subjects. The republic could use this pretext to influence the policies of the Antiochene monarchy under the pretense of defending the national minorities that were in danger. The aim of the messengers' trip was described by the author as tou arai ton dzygon, that is to free themselves from the yoke with the help of the republic. From a political point of view, this aim seems to be appropriate. However, the hagiographer considers it to be reprehensible in the way it is conducted. This is indicated by the short pericope of Lam 3:25-28 (LXX), which also includes the mentioned phrase. The author writes that the Lord is good to those who seek Him (v. 25), wait and expect salvation from Him (v. 26), bear a yoke (arē dzygon) in their youth (v. 27), and are silently enduring what the Lord has imposed upon them (v. 28). ${ }^{21}$ This description sheds important light on the situation of the Jews in Judea and shows the direction in which they should seek help. Verse 27 was mentioned here to stand in stark contrast to the actions of Judas and the leaders of the revolt. The hagiographer used a double-meaning verb airo which, depending on the context and in combination with the noun dzygos - 'yoke', might mean 'take, lift or hang', as it is the case in Job 6:2 or Mt 11:29. ${ }^{22}$ However, the verb might also mean quite the opposite, that is 'remove, take away, take off, end', as it is described in 1 Macc 8:18 and 13:41. ${ }^{23}$ But it is not only the opposite meaning of the verb which both passages have in common. There is also the opposite meaning in the context of the actions of the devout Israelite from the Book of Lamentations and the actions of Judas Maccabeus:

a) seeking the Lord (Lam 3:25) and seeking a pact with the Gentiles (1 Macc);

b) expecting salvation from the Lord (Lam 3:26) and expecting salvation from the Gentiles (1 Macc);

c) bearing one's own yoke from one's youth (Lam 3:27) and removing one's yoke with human help (1 Macc);

d) staying silent and perseverance in bearing the yoke imposed by the Lord (Lam 3:28) and arbitrary rejection of political captivity (1 Macc).

The comparison above clearly indicates that Judas's actions stand in dark contrast to the devout and faithful believer. These actions questioned Judas's difficult

${ }^{20}$ The senate played their cards right here, which the inspired author noted in his presentation of how the republic functioned.

${ }^{21}$ D. Garrett, P.R. House, Song of Songs, Lamentations, WBC 23B, Nashville 2004, pp. 415-416.

${ }^{22}$ Homer, Il 16,678; 24,583; Od 3,312; 21,18.

${ }^{23}$ Aeschylus, Eum. 847; Plato, Rep. 578e; Euripides, El. 942. 
political fate and treated it as God's will and punishment for the previous infidelity of the people. Therefore, Judas should have correctly read the theological meaning of the political situation of his country and borne his yoke instead of looking for uncertain support from the Gentiles. But does this mean that he should adopt the policy of defeatism and abandon fight for independence? Quite the opposite - the previous battles of Judas and of his father Mattathias brought spectacular results and revived the faith of the whole people, which obviously could not have happened without God's support. The point is not to replace God with a covenant with the Gentiles, for which one has to pay financially and offer absolute political loyalty. The historical and expensive pacts mentioned in the introduction to this article did not teach the leader of the Maccabean Revolt anything. These pacts were signed between the Judean king Asa and Ben-Hadad I, the king of Aram, between the Israeli monarch Ahab and Ben-Hadad II, the successor of the former, between the Judean king Ahaz and Tiglath-Pileser III, the ruler of Assyria, and between the Judean kingdom and Egypt (Isa 30:1-5).

The name 'the kingdom of the Hellenes' (tōn Hellēnon), which occurs in the analyzed verse most likely refers to the fragment of Isa 9:11a (LXX). It mentions the invasions of the Syrian troops from the East and of the Greeks on Judea from the West. These invasions are seen as a punishment for the infidelity of the chosen people. ${ }^{24}$ The context of v. 7-11 plays an important theological role here. It includes a description of the Lord pronouncing a sentence on the Israelites (v. 7). This sentence will become known to all the impertinent culprits who did their own people wrong (v. 8). They wanted to oppose divine providence and, in their pride, stick to their intentions (v. 9). Yet the Greek version presents an inexplicable turning point, which is totally contrary to the original meaning. In the Hebrew text, the Lord raised up the Gentile enemies of the rebellious Israelites and granted them dominance over His own people (v. 10). This dominance will allow the Arameans from the East and the Philistines from the West to literally 'devour' Israel (v. 11a). Such a version of this passage would make a great theological commentary to the situation described by the author of the First Book of Maccabees. According to him, the policies of Judas Maccabeus are imprudently related to those who, by definition, are the enemies of Israel, i.e. Seleucids now or Romans in the future. One should not repay anyone evil for evil but instead should rely on God who is faithful to His covenant and will let His people survive through the present turmoil and live to see peace. ${ }^{25}$ But the allusion to the

${ }^{24}$ T. Brzegowy, Księga Izajasza, rozdziaty 1-12, NKB.ST XXII/1, Częstochowa 2010, pp. 541-543.

${ }^{25}$ The Messianic announcement in Isa 9:1-6 has a close meaning to this statement. It stresses the radical change of fate in v. 1-2, which would have been impossible without God's help, see: T. Brzegowy, Księga Izajasza... [1], pp. 511-513. 
Hebrew text does not seem to be probable since the hagiographer refers to the Greek version all over. ${ }^{26}$ It is verse 10 onward from which the Hebrew version is totally different from the Septuagint. The translator wrote that God will bring down everyone who dare to take up arms against Mount Zion and its inhabitants and who lead to their total dispersion. This will happen to Syria which attacks Israel from the East and to the Hellenes who attack the nation from the West and intend to destroy it entirely (v. 11). In this context, Judas's policies should be evaluated rather positively because the republic could be God's scourge on the previous and current enemies of the chosen people. ${ }^{27}$ Such an interpretation is at odds with the previous meaning of the verse, which questioned the point of the pact that was being signed. This interpretation does not agree with the hagiographer's holistic approach to the policies of the following leaders of the revolt, who departed more and more from the provisions of the covenant that the patriarch and father Mattathias reminded them about (2:50-64). It is quite the opposite! In order to understand the mentioned interpretation, it is important to compare the context of a prophecy and a situation described in the First Book of Maccabees:

a) God's sentence on Israel, which is temporally unknown to the culprits (Isa 9:7/1 Macc);

b) tough inhabitants of Israel will know this sentence (Isa 9:8), similarly to Judas, who will be killed in combat with his enemies. The sentence will also become known to the unfaithful insurgents who supported Judas in his political endeavors (1 Macc);

c) arbitrary and proud substitution of past war damage with better protection (Isa 9:9) and arbitrary replacement of God with an agreement with the Roman republic (1 Macc);

d) God's counteraction resulting in the death and dispersion of Judas's enemies fighting on both sides of the country and Jonathan's, the successor of Judas's, actions resulting in the defeat of the multinational Seleucid empire (1 Macc). Jonathan was faithful to the Lord in the initial phase of his leadership.

${ }^{26}$ It is a well-known fact that there likely was an earlier version of the Hebrew First Book of Maccabees. Assuming that its author also applied intertextual allusions, he would have been able to use the original theology of Isa 9:10-11a. Recent research confirms that the Hebrew original of the book existed, see: G. Darsham, The Original Language of 1 Maccabees: A Reexamination, BN (NF) 182 (2019), pp. 91-110.

27 The theology of Gentiles as a whip in the hands of angry God is well documented in the Old Testament. For instance, Isa 10:5-19 includes two important elements: punishment for Israel's infidelity and an announcement of the Gentiles' extermination because of their 'overeagerness' in the fight with the Lord's people, see: H. Wildberger, Isaiah 1-12: A Continental Commentary, Minneapolis 1991, pp. 416-433. 
The composition of the First Book of Maccabees requires that the new times of Jonathan's leadership should be inspected. These times occurred after the death of Judas, who was evaluated by the hagiographer as someone defiant and who resembled the inhabitants of the Northern Kingdom of Israel subjected to the authority of Assyria (Isa 9:8-9). ${ }^{28}$ The mention of Hellenes in the Greek version of Isa 9:11 might refer to the post-exile verse of Zech 9:13 (LXX) including a prophecy about the kingdom of Judah and Israel, which will defeat the Hellenes as the Lord Himself will give them sufficient strength. This moment is decisive in understanding the meaning of the message included within the Greek version of Isaiah - Zion - does not have to rescue itself but has to completely rely on His assistance resulting from the fidelity to the covenant. ${ }^{29}$

Since God Himself will wreck havoc in the armies of the enemies of His people, it does not make any sense to enter into a political relationship with any of them. Even when they gain advantage and mercilessly oppress the people, they will never be able to eliminate them completely as the Lord will rescue Israel under His covenant. And the people of Israel will do penance through the sufferings of their oppression. The Gentiles will be completely exterminated, for they wanted to kill the chosen people. ${ }^{30}$ Assuming that the Lord arranged for such a situation to happen, seeking a solution beyond Him, as Judas presently wants, is pointless. Both texts, i.e. Lam and Isa, perfectly complement each other as to the current situation in Judea and suggest tips how to resolve it. This situation results from Jewish infidelities to God Himself.

The use of the verb katadouloo,, which translates as 'I enslave', leads in the same direction. The Seleucid monarchy is presented as trying to keep in captivity (katadouloumenous) its rebellious province. The verb in question is likely an echo of the prophecy uttered in Jer 15:14 (LXX). The context of Jer 15:12-14 is extremely difficult to interpret. It is contrasting with the previous complaint of the prophet about his cruel fate despite the actions he undertook to rescue the people of Judah (v. 10-11). ${ }^{31}$ Yet verse 12 changes the interlocutor to angered

${ }^{28}$ G.V. Smith, Isaiah 1-39: An Exegetical and Theological Exposition of Holy Scripture, NAC 15A, Nashville 2007, pp. 245-246.

${ }^{29}$ Many exegetes point to the term $j \bar{a} w \bar{a} n$, i.e. Greece, which acquired a military meaning much later, that is following the wars of Alexander the Great and the capture of Asia and Egypt and the beginning of the Hellenistic epoch. The prophet Zechariah delivers his address on behalf of God and forecasts the beginning of a new era that the Maccabees will have to face. Many researchers agree that the victory of God announced in Zech 9:13, which inaugurated His kingdom, happened in $165 \mathrm{BC}$ when Judas captured Zion and rebuilt temple worship, see: G.L. Klein, Zechariah: An Exegetical and Theological Exposition of Holy Scripture, NAC 21B, Nashville 2008, pp. $277-278$.

${ }^{30}$ Isa 47:6; Jer 51:24,34-35; Ezek 25:3-7,12-17; 26:2-6; Zech 1:14-15; 12:9.

${ }^{31}$ Verse 15 returns to the prophet's speech which begs the Lord to notice all the injustice that the prophet suffered from his adversaries. 
God who appears not to listen to the complaints of His prophet. He asks a rhetorical question about the strength of His message in which the Judeans place trust (v. 12). The answer might be unequivocal although it is not uttered explicitly in the text, perhaps because it is so obvious. Hence further decisions from the Lord - he will give the people's treasures as plunder as a result of the misdeeds committed on the territories belonging to Judah (v. 13). The people themselves will be held captive (katadoulosso) by their foes in the country which they do not know, because the Lord sparked anger over the stubborn and foolish Judeans (v. 14). ${ }^{32}$ All the three verses perfectly express the theological evaluation of the situation that the author of the First Book of Maccabees wants to present to the reader. Another list of common features will enable the reader to see a close relationship between both contexts:

a) God's question about the strength of any arms that are against His decisions (Jer 15:12) as a commentary to the policies of Judas Maccabeus, who trusted the military power of the republic and the sincerity of the senate too much (1 Macc);

b) a forecast of the inhabitants being stripped of their belongings as a punishment for their defiance and disobedience (Jer 15:13) and a forecast of persecution in the country after the defeated battle of Elasa or, in a further perspective, as a result of Romans' expected actions in Judea (1 Macc); ${ }^{33}$

c) the people being taken captive by their enemies in an unknown country as a result of God's rage for their impenitence (Jer 15:14) and being confined to Seleucid, and later Roman, captivity for a second time, where Roman confinement resulted from the stubbornness in forcing through the pact with Romans (1 Macc). ${ }^{34}$ 392.

32 Compare this with the Hebrew original, J.A. Thompson, The Book of Jeremiah ..., pp. 391-

${ }^{33}$ The same thing happened when king Ahaz negotiated with Tiglath-Pileser III (2 Kings 16:7-9; 2 Chr 28:16-21) and 30 years later Assyrians stood at the gateway of Jerusalem and only divine intervention rescued the city (2 Kings 19:35).

${ }^{34}$ One of the more important achievements of intertextual analysis is the possibility of comparing particular verses for the purpose of finding theological relations that were intended by the inspired author. But intertextual analysis is also about the possibility of building these relations between the inspired author and the reader. It is the reader who is allowed to search for his own legitimate, that is consistent with the hagiographer's message, theological conclusions, see: K. Nielsen, Intertextuality and Biblical Scholarship, SJOT 4 (1990) 2, pp. 90-92; J.M. Pucci, The Full-Knowing Reader: Allusion and the Power of the Reader in the Western Literary Tradition, New Haven 1998. M. Fishbane called this process 'aggressive exegesis' - 'it mainly concerns the use of a full range of inherited traditum (i.e. the material for further dissemination and inspection - J.N's note) for the purpose of acquiring new theological observations, attitudes and speculations'. Aggressive exegesis concerns 'hidden and unexpected meanings' in traditum and 'makes this whole potential real', M. Fishbane, Biblical Interpretation in Ancient Israel, Oxford 1988, p. 283. 
Verse 12 might be interpreted in two ways: either Judas overly believed in the possibilities of his arms after numerous victorious battles with the Seleucid troops or he stopped seeking help from the Lord by forgetting that it is only Him who offers proper strength..$^{35}$ Having realized his own insufficiency, Judas reached for help from another Gentile country instead of relying on God, who is always faithful to the covenant. Again, he trusted the military power of the mightiest empire on the political scene of that time. While the passage of Isa 30:1-5 analyzed earlier speaks of shame that Judeans will experience because they relied on the weak and helpless Egypt, the situation here seems to be quite the opposite. Judas relies on the power of the invincible Roman republic. Therefore, shame will come but due to a different reason - the current allies will become the worst oppressor of the chosen people ${ }^{36}$ in the future, as it was forecast by Jeremiah. It is now difficult to evaluate whether the inspired author prophesies the future that Judeans will experience from Romans in several dozen years from the moment Pompey the Great seizes Palestine for the first time. Most probably, however, the hagiographer does not reach this far as he does not want to prophesy like a classical prophet of Israel would. He reaches for the centuries-old experience of Israel which could not expect any friendly relations from a Gentile nation. Superpowers such as Egypt, Assyria, Babylonia along with the minor neighboring countries are among the greatest oppressors of the chosen people that caused them difficulties, wars and persecution. This experience should have dominated in the political efforts of Judas Maccabeus, the leader of combat against another Gentile superpower - the Seleucid empire.

There is also a remark the Seleucid empire attempts to Israēl douleiā, i.e. bring 'Israel into captivity'. The people experience the burden of solitary fight with more powerful enemies, because ultimately only God can truly liberate His people from captivity, as He forecast through his prophets. ${ }^{37}$ This liberation will not happen with the help of Gentiles. The history of Israel should be a sufficient argument to support this thesis.

35 This conclusion is brought to mind despite Judas's earlier declaration that God does not care about the greatness of human initiative. The less power a believer has, the greater help he receives from the Lord (1 Macc 3:18-19). Meanwhile Judas decided to attack the Acra without permission and placed a lot of trust in the power of his troops. Having been forced to refrain from attack (1 Macc 6:32), he would have had to focus on the battle with the army of Antiochus V. For the first time, he was unable to keep his belongings, which resulted in the necessity to back off from the city. For a holistic analysis, see: J. Nawrot, Dlaczego oni zwyciężają? Teologiczna ocena judejskiej kampanii Antiocha V Eupatora w 1 Mch 6,47-54, SG 31 (2017), pp. 85-103.

${ }^{36}$ Similar to Ezek $16: 37 ; 23: 9,22-26$.

${ }^{37}$ Ex 6:6; Judg 6:8; Ier 41:13. 


\section{A Trip to the Capital of the Republic}

\section{8:19: After making a very long journey to Rome, they went to the senate chamber and spoke as follows:}

By stating in verse 19 that the journey to Rome was long, the author does not want to inform the reader merely about the distance between Jerusalem and the capital of the republic. The expression eporeuthesan eis..., which translates as 'they went to', might be an allusion to the prophetic text of Jon 3:3 (LXX), where the phrase eporeuthe eis, that is 'he went to' Nineveh, serves to preach repentance to the big city. ${ }^{38}$ The author refers to this place and wants to show a contrast in the subsequent contextual comparison:

a) the sender: God (Jon) and an initiative of the insurgents (1 Macc);

b) the addressee of the mission: a journey to Nineveh (Jon) and a trip to Rome (1 Macc);

c) the objective of the mission: assistance offered to the Gentiles for the purpose of saving their lives (Jon) and gaining help from them (1 Macc);

d) the character of the mission: preaching God's word to the Gentiles in order to convert them (Jon) and relying merely on the secular side of the political pact (1 Macc).

Any potential contacts with the Gentiles should be preceded with an absolute and strong will to remain faithful to the Lord ${ }^{39}$ regardless of the ways that other nations adapt ${ }^{40}$ Conversely, other nations should arrive (poreusontai) in Jerusalem in order to get to know the Lord's Law and follow in His footsteps [Mic 4:2; Isa 2:3 (LXX)].

The further remark that the trip to Rome was very long (hodos polle sfodra) gives the impression of enormous effort that the messengers had to take to reach their destination. The first two words most likely refer to 1 Kings 19:7 (LXX), which presents God's imperative directed at the prophet Elijah to set out on a long expedition. It is important to note that he lived off a modest meal that would be sufficient for 40 days and nights. ${ }^{41}$ The context of 1 Kings 19:1-8, where contrasting situations are presented, has the following features: ${ }^{42}$

${ }^{38}$ D. Stuart, Hosea - Jonah, WBC 31, Waco 1987, pp. 482, 486-488.

39 The similar construction poreusometha en onomati kyriou theou hēmōn can also be found in the prophetic quotation of Mic 4:5.

${ }^{40}$ The imperative of the entire people to remain faithful to God has been expressed through poreusontai hekastos tên hodon autou, as it is noted in Deut 30:16.

${ }^{41}$ J.B. Łach, Księgi 1-2 Królów. Wstęp - przekład z oryginatu — komentarz - ekskursy [in:] PŚST, vol. 4, pt. 2, Poznań 2007, p. 339.

${ }^{42}$ For a detailed division of biblical material, see: B.O. Long, 1 Kings with an Introduction to Historical Literature, FOTL IX, Grand Rapids 1984, pp. 196-197. 
a) persecution of Elijah by Ahab and Jezebel (1 Kings 19:1-3) and persecution of Jews by the Seleucid empire (1 Macc);

b) desire for death as an ending to the hardships of struggle (1 Kings 19:4) and desire for help in combat (1 Macc);

c) the first angelophany with an imperative to eat the miraculously prepared meal (1 Kings 19:5-6) and the exclusion of God in the efforts to establish peace in the country (1 Macc);

d) the second angelophany with an imperative to set out on a long expedition [polle (...) hodos] to reach the destination (1 King 19:7-8) and Judas's own initiative to realize his objective (1 Macc).

Although there were similar circumstances where a fair cause was persecuted, different initiatives were undertaken. For instance, Elijah relied solely on the Lord, experienced weaknesses of the flesh but did not see the possibility of resisting the enormity of the hardships he had to deal with. Elijah did not feel like taking any initiative on his own and desired death due to exhaustion. Meanwhile Judas wished to willfully take charge of the independence movement while forgetting that everything depends on God's will. The second element of contrast is the presence of God's angel who offered the prophet a meal. Without this meal, he would not have been able to continue his journey or his mission in general. This allowed God to completely revive the prophet's faith and his conviction about the closeness of God, who endangers His servant yet never stops looking after him. ${ }^{43}$ Judas, quite to the contrary, expected nothing from God since he found help in the covenant with a Gentile empire. ${ }^{44}$ Judas's messengers to Rome cannot expect God to help them in their undertaking since they set out not by order of Him but because of strictly human initiative.

The hagiographer's allusion to Josh 9:1-13 (LXX) might be equally interesting. It contains a whole set of terms used in 1 Macc 8:19. Having come to Joshua, the messengers from Gibeon mentioned a very long journey (polless hodou sfodra) that they allegedly went on in order to make a covenant with him. The background of this event described in Josh 9:3-15 (LXX) is important here as it constitutes a closer context of the political pact in the First Book of Maccabees. This context speaks of contrasting conduct while retaining some situational similarities:

${ }^{43}$ P.R. House, 1-2 Kings: An Exegetical and Theological Exposition of Holy Scripture, NAC 8, Nashville 1995, p. 222.

${ }^{44}$ In the analyzed verse from the First Book of Maccabees, the reader might also find a certain theological reference to 1 Sam 26:13, which accentuates a wide distance (polle he hodos) that set David, who was harassed by Saul, apart from him. This comparison might be interpreted as a demand to stick to the Lord and stay away from the persecutor instead of looking for close contact with a possible oppressor. 
a) news gathered by the people of Gibeon about the successes of Joshua (Josh 9:3) and Judas's news about Romans (1 Macc 8:1-16);

b) Gibeonites (=Gentiles!) asking Israelites to sign a pact (Josh) and Jews asking Romans to sign an agreement (1 Macc);

c) Gentiles' deceit toward Israelites (9:4-13) and Jews' honest will to sign a pact with Gentiles (1 Macc);

d) Israelites' lack of contact with God in taking decisions (Josh 9:14) and the same lack of contact from Judas (1 Macc);

e) Joshua's approval for the covenant (Josh 9:15) and the same approval from the Roman senate (1 Macc 8:21-32).

The list above indicates that the insurgents made two basic mistakes that could have been avoided if they had more thoroughly inspected the history of their nation. The first mistake concerned failure to seek God's advice in such important situations as signing a covenant with a Gentile nation. While Joshua might have committed a mistake through inattention or neglect, Judas acted intentionally and ignored God in his politics. The second mistake concerned the naive conviction that Gentiles would turn out to be honest in their agreements with Jews. The gullibility of the Israelites from Joshua's environment toward the Gentiles' declarations resulted in failure to implement the provision from Deut 7:1-2. Similarly, Judas would soon learn through his solitary fight with the Seleucid troops and through dying afterwards that one cannot rely on the assurances of the Roman senate.

Equally important theologically is the expression that the Jewish messengers apekritessan kai eipon, that is 'spoke and said', while entering the senate. The prophecy from Isa 14:10 (LXX) speaks of a future downfall of an unknown empire which currently remains in its prime. ${ }^{45}$ The closer context of v. $4 \mathrm{~b}-21$ constitutes a poetic elegy about a fallen tyrant that sounds distinctively like a sneer over the fate of the person who saw himself as a center of the world and believed that nothing was impossible for him. ${ }^{46}$ There are four stanzas in the complicated structure of this composition: v. 4b-8; 9-11; 12-15 and 16-21. The closest contextual frame of the verse in question is built around verses 9-11, where the main topic concerns the descent of the deceased king to Sheol. In this place, impotent shadows of the fallen heroes, kings and noblemen ${ }^{47}$ receive the king. The poem convinces the reader that no national superpower will last forever as God exercises power over everything. Similarly to other empires which fell and

${ }^{45}$ The threat is expressed with the construction apokrithēsontai kai erousin, which is a calque of the Hebrew expression wa ‘̆nû wajjôm ${ }^{e}$ ru, see: G.V. Smith, Isaiah 1-39, p. 314.

${ }^{46}$ L. Stachowiak, Księga Izajasza I 1-39. Wstęp - przektad z oryginatu - komentarz, [in:] PŚST, Poznań 1996, p. 283-284.

${ }^{47}$ T. Brzegowy, Księga Izajasza. Rozdziaty 13-39, NKB.ST 22/2, Częstochowa 2014, p. 69. 
whose rulers are currently in Sheol, the mighty monarch will also fall, which the deceased are going to portend (apokrithèsontai kai erousin, 14:9). The allusion between Babylon and Rome made by the hagiographer prophesies the fate of the latter superpower, the fate which already happened to the former empire. At that time, Rome was in its prime and did not want to respect the pact with the Jewish people. For a superpower such as Rome, Jews were not an equal partner. Such an attitude would put Rome at a disadvantage and lead to their downfall. After all, the Lord would stand up for His people and administer justice to those who deceived and used ${ }^{48}$ the chosen people even when they committed mistakes and remained unfaithful to the covenant. The Gentiles would die, as it was the case with Egypt, Assyria and Babylonia. It is a paradox that the Jews who came for help apekritêsan kai eipon to the senate would become an involuntary harbinger of the future downfall of the mighty empire. For Judas and his insurgents, the memory of this downfall should become a serious warning against engaging in an uncertain political relationship with a Gentile nation.

The poem from the Book of Isaiah contains, according to some exegetes, some important elements of how the Jewish community functioned including tension between different social groups within the mentioned community. Scoundrels who are full of arrogance and pride and who are convinced that they are allowed to do whatever they please come under attack here (v. 4b,12-14,16-17). What is visible here is the whip (v. 5-6) used against the culprits and a spectacular turn of the tide where glory, mightiness and self-esteem turn into poverty, hopelessness and death. The terms $r^{e} \check{s}^{\prime} \bar{a}$ ' $\hat{\imath} m$, which translates as 'scoundrels' (v. 5), and $m^{e} r \bar{e}$ ' $\hat{\imath} m$, that is 'villains' (v. 20), ${ }^{49}$ traditionally denote the contemptible inhabitants of the Southern kingdom..$^{50}$ If one were to look at the period of the revolt from this perspective, satire could also be applied to Judas's conduct as he was overconfident in his and his army's potential. Moreover, he saw himself as the leader of the people, similarly to other rulers, and owed this position to the politico-military pacts he had signed. He also wanted to be counted among the mightiest of this world. Judas would soon experience bitter disappointment when the republic disregarded its own obligations and when he descended to Sheol after dying in his last battle. At that time, the words uttered by the Jewish messengers to the senate might be interpreted as a swansong on behalf of the leader who would die soon. Along with him would die the intricately drafted project of the grand political alliance that ultimately turned out to be an empty and unrealized dream due to the lack of God's support.

${ }^{48}$ See: Joel 4:1-8; Zeph 2:8-10; Isa 10:5-19; 52:1-6; Ezek 25:12-17; 39:7.

49 Ps 26:5; 37:9-10; Prov 4:16-17; 24:18-19.

${ }^{50} \mathrm{~J}$. Vermeylen, Du prophète Isaïe à l'apocalyptique. Isaïe I-XXXV, miroir d'un demimillénaire d'expérience religieuse en Israël, Tome I, Paris 1977, p. 295. 


\section{The Messengers' Speech to the Roman Senate}

\section{8:20: Judas Maccabeus, and his brothers and the people of Judea have sent us to you \\ to establish alliance and peace with you, so that we may be enrolled as your allies and friends.}

The speech above is a typical request of an inferior to a superior. The Jews stood in a line to the senate because the dangerous situation in the province forced them to do so. They needed help from Rome. One might expect that the pact would be more convenient for Rome rather than Jews. The messengers' speech begins with the presentation of the authors of the whole initiative - the leaders of the revolt and the entire people. Since Alcimus's environment in Jerusalem was hostile to Judas, the phrase plèthos tōn Ioudaiōn should refer to all those who were in favor of the Hellenization of the country. It was important to show the widest consensus of the Jewish community which sent (apesteilan) their messengers with a mission. The mention of 'the people' is supposed to add representativeness to the Jewish proposal, particularly because Judas did not receive approval from the most important religious superior, that is the archpriest, with whom Judas was in constant conflict. Although plēthos tōn Ioudaiōn occurs in one verse only in the Greek bible, the Septuagint notes the passage 2 Kings 7:12-14 (LXX) which includes a derivative expression plèthos Israèl (v. 13). The context here speaks of an uncertain situation that the king of Israel found himself in. This situation involved a fight against the Syrian foe during a common and devastating famine. The horses which were still alive were sent (aposteloumen) with two horsemen to check what was happening in the adversary's camp. ${ }^{51}$ The composition of v. 12-14 corresponds well with the situation of Judas Maccabeus and his insurgents in the First Book of Maccabees:

a) the declaration of a difficult position of Israeli troops and possible deceit from the enemy (v. 12) along with a mission to Rome to announce the situation in Judea (1 Macc);

b) a proposal to send scouts as a response to the situation (v. 13) and the mission to Rome (1 Macc);

c) the decision to act according to the proposal (v. 14) and the senate's decision to help the Jews (1 Macc).

In the Second Book of Kings, the messengers lack an interlocutor, but their activities are quite effective. They are sent to Rome as envoys, and they read a notice about the severity of their situation. It is, however, important to note that the entire situation is happening in the atmosphere of extreme anxiety about the

${ }^{51}$ J.B. Łach, Księgi 1-2 Królów..., p. 422. 
expected effects of the whole undertaking. Similarly, the expedition of Judas's two envoys to Rome carries a substantial risk of failure as it is obviously an activity that goes beyond God's will.

The objective of the mission was to establish an 'alliance' (symmachia) and 'peace' (eirēne $)$ with the republic. ${ }^{52}$ The high probability of failure is confirmed by Strabo, who writes that peace (eirēnē) and the alliance (symmachia) might only be established when Rome approves or when its expectations are met as Rome exercises control over numerous provinces (Geography, 14:3,3). The remark made by the Greek geographer, historian and traveler shows a disproportion of both partners of the political pact. It also reveals Jews' throwing themselves at the mercy of the senate and complete manipulation of their fate in the interests of the republic. The final combination of symmachos and filos refers to the principles of the treaty that will be presented in the following verses, namely in the senate's letter to Jews (v. 23-32) and in the earlier Roman customs that the author noted (v. 11,17). The terms in question are strictly political names that are well-known in Greek literature. ${ }^{53}$ Besides the very context of the First Book of Maccabees, the Septuagint does not mention phrases like this. ${ }^{54}$ One should not overlook the fact that everything is happening in conflict with the only permissible covenant that was once made between the Lord and his people on Zion (Deut 7:1-2). Although this covenant has nothing to do with the peoples and countries closest to Israel, failure to abide by it puts the leaders of the revolt and the entire people at the risk of losing faith and fidelity to the God of Israel and in danger of being subjected to the laws declared by another Gentile empire.

\section{Conclusions}

All in all, the remarks above point to the following elements of the exegesis in the analyzed passage:

a) an intertextual analysis based primarily on the same terminological constructions; it appears to be the most relevant method to determine deeper relations between particular verses of the book;

${ }^{52}$ Both terms relate to the signed treaties and are well-known in non-biblical literature, Thucydides, Hist. Pel. 4,19.1; Polybius, Hist. 4:15,8-9; 6:14,10-11; Plutarch, Nic. 10,2-3; Arat. 33,1; Tit. 5,6; Arrian, Anab. Alex. 3:24,5; Diodorus, Bibl. 19:75,6.

${ }_{53}$ The expressions symmachos and filos point to their political meaning (Aeschines, Leg. 2,9; Ctesiph. 3,61; Demosthenes, Leg. 143,334; Lep. 59; Euripides, Phoen. 535; Plato, Men. 94d; Plutarch, Alc. 26,1; Xenophon, Anab. 1:3,6; Cyrop. 6:4,13; Flavius Josephus, Ant. 5:1,16,55; $13: 1,5,24 ; 13: 2,2,43 ; 13: 5,4,145 ; 14: 10,8,214,216 ; 17: 9,6,246 ; 20: 3,1,59)$, see: http://www.perseus.tufts.edu/ [permanent access].

${ }^{54}$ They can also be found in the analyzed book in $8: 31 ; 10: 16 ; 12: 14 ; 14: 40 ; 15: 17$. 
b) the Greek text of the Old Testament might possess its own intertextual relations irrespective of the Hebrew original, as it is the case with 1 Macc 9:18 and Isa 9:11;

c) despite such a narrow research area as the First Book of Maccabees, which the present article is representative of, it seems that the most important role in establishing intertextual relations is played not only by the intended terminological construction, but mainly by the context of the events that are happening; in all of the analyzed textual relations, the comparability of this context has a prime meaning;

d) the decisive role of context in the analyzed verses and its intertextual allusions makes the theological milieu of an expression stand out more than its primary meaning in the hagiographer's evaluation of the actions of the main character;

e) in order to discover a deeper theological spectrum of particular verses linked with allusions, the hagiographer might relate to one or more texts that these allusions refer to, e.g. 1 Macc 8:17, Jer 43:21 and 2 Kings 18:17 in the comparison of the verbs apostello- - histēmi, as well as 8:19, 1 Kings 19:7 and Josh 9:13 in the expression hodos polle sfodra; reference to two different texts enables the reader to evaluate the conduct of two addressees in a different light. It also allows for uncovering certain factors related to motivation or modus operandi; in order to properly read this type of allusion, there needs to be a total lack of textual and theological contradiction.

Translated by Mateusz Sylwestrzak

\section{Teologiczna ocena przymierza Judy Machabeusza z Rzymem. Intertekstualna analiza 1 Mch 8,17-20}

\section{Streszczenie}

Jaka była biblijna interpretacja postępowania Żydów w końcowym etapie historii Izraela w świetle zapisów prawa Mojżeszowego, niemal tuż przed nastaniem czasów Nowego Testamentu? Proponowana egzegeza fragmentu 1 Mch 8,17-20, opisującego zawarcie przymierza przez Judę Machabeusza z republiką rzymską, pragnie ukazać teologiczną ocenę postępowania przywódcy powstania dokonaną przez autora księgi. Najbardziej pomocne w wydobyciu właściwego rozumienia tekstu okazuje się podejście intertekstualne. Pozwala ono celowo łączyć sformułowania kolejnych wersetów z tymi samymi zwrotami wcześniejszych ksiąg biblijnych. Zawarta w nich teologia ukaże właściwy sens zaproponowanego passusu Pierwszej Księgi Machabejskiej. Okazuje się, że ocena teologiczna jest daleka od oceny politycznej, branej niemal wyłącznie pod uwagę w ana- 
lizach i komentarzach historyczno-literackich. Autor biblijny zachowuje daleko idącą wstrzemięźliwość wobec politycznych sukcesów Machabeuszy, pragnąc ukazać ich postępowanie w świetle prawa Bożego. Mocno zaświadcza to o uzasadnionej przynależności Pierwszej Księgi Machabejskiej do korpusu pism natchnionych.

\section{Słowa kluczowe}

Septuaginta, Pierwsza Księga Machabejska, republika rzymska, przymierze, intertekstualność

\section{Keywords}

Septuagint, the First Book of the Maccabees, Roman republic, alliance, intertextuality

\section{Abbreviations}

\section{Ancient writings (available on: https://www.perseus.tufts.edu/)}

$\begin{array}{ll}\text { Alc. } & - \text { Plutarch, Alcibiades } \\ \text { Anab. } & - \text { Xenophon, Anabasis } \\ \text { Anab. Alex. } & - \text { Flavius Arrianus, Anabasis Aleksandrou } \\ \text { Ant. } & - \text { Flavius Josephus, Antiquitates Iudaicae } \\ \text { Arat. } & - \text { Plutarch, Aratos } \\ \text { Bibl. } & - \text { Diodorus Siculus, Bibliotheca } \\ \text { CAp. } & - \text { Flavius Josephus, Contra Apionem } \\ \text { Ctesiph. } & - \text { Aeschines, Contra Ctesiphon } \\ \text { Cyrop. } & - \text { Xenophon, Cyropaedia } \\ \text { El. } & - \text { Euripides, Electra } \\ \text { Eum. } & - \text { Aeschylus, Eumenides } \\ \text { Hist. } & - \text { Polybius, Historiae } \\ \text { Hist. Pel. } & - \text { Thucidydes, Historia tou Peloponnēsiakou } \\ \text { Leg. } & - \text { Demosthenes, De falsa legatione } \\ \text { Lep. } & - \text { Demosthenes, Contra Leptinus } \\ \text { Men. } & - \text { Plato, Menon } \\ \text { Nic. } & - \text { Plutarch, Nicias } \\ \text { Panath. } & - \text { Isocrates, Panathennaikos } \\ \text { Phoen. } & - \text { Euripides, Phoenissae } \\ \text { Rep. } & - \text { Plato, Republica } \\ \text { Tit. } & - \text { Plutarch, Titus Auintus Flaminius }\end{array}$




\section{Others}

$\begin{array}{lll}\text { AB } & - & \text { The Anchor Bible } \\ \text { BibAN } & - & \text { Biblical Annals } \\ \text { BN (NF) } & - & \text { Biblische Notizen (Neue Folge) } \\ \text { CBQ } & - & \text { Catholic Biblical Quarterly } \\ \text { FOTL } & - & \text { The Forms of the Old Testament Literature } \\ \text { NAC } & - & \text { The New American Commentary } \\ \text { NICOT } & - & \text { New International Commentary on the Old Testament } \\ \text { NKB.ST } & - & \text { Nowy Komentarz Biblijny. Stary Testament } \\ \text { PST } & - & \text { Poznańskie Studia Teologiczne } \\ \text { PŚST } & - & \text { Pismo Święte Starego Testamentu } \\ \text { SG } & - & \text { Studia Gnesnensia } \\ \text { SJOT } & - & \text { Scandinavian Journal of the Old Testament } \\ \text { WBC } & - & \text { Word Biblical Commentary }\end{array}$

\section{Bibliography}

Bar-Kochva B., Judas Maccabaeus: The Jewish Struggle Against the Seleucids, Cambridge 2002.

Brzegowy T., Księga Izajasza, rozdziaty 1-12, NKB.ST XXII/1, Częstochowa 2010.

Brzegowy T., Księga Izajasza, rozdziały 13-39, NKB.ST XXII/2, Częstochowa 2014.

Darsham G., The Original Language of 1 Maccabees: A Reexamination, BN (NF) 182 (2019), pp. 91-110.

Fishbane M., Biblical Interpretation in Ancient Israel, Oxford 1988.

Garrett D., House P.R., Song of Songs, Lamentations, WBC 23B, Nashville 2004.

Gera D., Judaea and Mediterranean Politics: 219 to 161 B.C.E., Leiden-New York 1998.

Goldstein J., I Maccabees: A New Translation, with Introduction and Commentary, AB 41, Garden City 1976.

House P.R., 1-2 Kings: An Exegetical and Theological Exposition of Holy Scripture, NAC 8, Nashville 1995.

Keown G.L., Scalise P.J., Smithers T.G., Jeremiah 26-52, WBC 27, Dallas 1995.

Klein G.L., Zechariah: An Exegetical and Theological Exposition of Holy Scripture, NAC 21B, Nashville 2008.

Laskowski Ł., Druga Księga Machabejska, NKB.ST XIV/3, Częstochowa 2017.

Long B.O., 1 Kings with an Introduction to Historical Literature, FOTL IX, Grand Rapids 1984.

Łach J.B., Księgi 1-2 Królów. Wstęp - przekład z oryginału - komentarz - ekskursy [in:] PŚST, vol. IV, p. 2, Poznań 2007.

Mandell S.R., Did the Maccabees Believe that They Had a Valid Treaty with Rome?, CBQ 53 (1991) 2, pp. 202-220. 
Nawrot J., Alliances between Israel and Other Nations in Light of the Pentateuch's Prohibitions in the Greek Bible, PST 35 (2020), pp. 29-48.

Nawrot J., Aluzje literackie $w$ teologicznej ocenie działań arcykapłana Szymona w 1 Mch 14,5, BibAn 11 (2021) 1, pp. 5-23.

Nawrot J., Dlaczego oni zwyciężają? Teologiczna ocena judejskiej kampanii Antiocha V Eupatora w 1 Mch 6,47-54, SG 31 (2017), pp. 85-103.

Nawrot J., Izrael wobec zakazu sprzymierzania się z poganami w wybranych tekstach Septuaginty: część I, PST 34 (2019), pp. 7-28.

Nielsen K., Intertextuality and Biblical Scholarship, SJOT 4 (1990) 2, pp. 89-95.

Oropeza B.J., Quotes, Allusions, and Echoes: Some Thoughts about What They Mean in Reference to Biblical Scripture, https:/www.academia.edu/38547991/Quotes_Allusions_and_Echoes_Some_Thoughts_about_What_They_Mean_in_Reference_to_ Scripture.

Pucci J.M., The Full-Knowing Reader: Allusion and the Power of the Reader in the Western Literary Tradition, New Haven 1998.

Rocca S., The Late Roman Republic and Hasmonean Judaea, Athenaeum 102 (2014) 1, pp. 47-78.

Seeman C., Rome and Judea in Transition: Hasmonean Relations with the Roman Republic and the Evolution of the High Priesthood, New York 2013.

Smith G.V., Isaiah 1-39: An Exegetical and Theological Exposition of Holy Scripture, NAC 15A, Nashville 2007.

Stachowiak L., Księga Izajasza I 1-39. Wstęp — przekład z oryginatu — komentarz [in:] PŚST, Poznań 1996.

Stern M., The Treaty between Judaea and Rome in 161 BCE, "Zion" 51 (1986), pp. 3-28.

Stuart D., Hosea - Jonah, WBC 31, Waco 1987.

Thompson J.A., The Book of Jeremiah, NICOT, Grand Rapids 2007.

Vermeylen J., Du prophète Isaïe à l'apocalyptique. Isaïe I-XXXV, miroir d'un demimillénaire d'expérience religieuse en Israël, t. 1, Paris 1977.

Wildberger H., Isaiah 1-12. A Continental Commentary, Minneapolis 1991.

Zollschan L., The Senate and the Jewish Embassy of 161 BCE [in:] The Path of Peace: Studies in Honor of Israel Friedman Ben-Shalom, ed. by D. Gera et al., Beersheva 2005, pp. 1-37. 